\title{
メリライト族鉱物のインコメンシュレート構造における 大規模規則性とその温度変化
}

\author{
日本原子力研究開発機構 量子ビーム応用研究部門 日下勝弘
}

Katsuhiro KUSAKA: Investigations on the Large-scale Regularities and Their Thermal Change in the Modulated Structures of the Melilite Group

The structures of the melilite (three compounds) have been determined in the range from room temperature up to $773 \mathrm{~K}$. The structures of incommensurate (IC) phase are characterized by bundles of four arrays of the six-coordinated Ca polyhedra with $\mathrm{T}^{1}$ tetrahedra along the c-axis. The IC phases undergo the phase transition into the normal phases at elevated temperatures. The change of the modulated structure has been clarified by construction of the structures using the desired $q$-values and the modulation amplitudes determined at $293 \mathrm{~K}$. The change of IC structures is characterized by variable distribution of bundle and octagonal arrangements of them. Large-scale regularities with sizes much larger than the modulation wavelength are also formed in the structures. The structure of commensurate phase of $\mathrm{Ca}_{2} \mathrm{CoSi}_{2} \mathrm{O}_{7}$ has been determined based on the results of simulation.

\section{1. はじめに}

メリライト (和名：黄長石) 族鉱物は地球の岩石中, あ るいは隕石中に構成鉱物として産出するほか, 鉄製錬の過 程で生じるスラグ中にも普通に見られる物質である.また 比較的簡単な一般化学式を有することから,さまざまな元 素の組み合わせで合成が試みられ成功している. 一般化学 式とこれまでに明らかにされている構成元素は下記のと おりである.1

一般化学式： $\mathrm{X}_{2} \mathrm{~T}^{1} \mathrm{~T}_{2}{ }^{2} \mathrm{~A}_{7}$,

$\mathrm{X}: \mathrm{Ca}, \mathrm{Na}, \mathrm{Sr}, \mathrm{Ba}, \mathrm{Pb}, \mathrm{Y}, \mathrm{La}, \mathrm{Pr}, \mathrm{Sm}, \mathrm{Gd}, \mathrm{Dy}, \mathrm{Er}$,

$\mathrm{T}^{1}: \mathrm{Be}, \mathrm{Al}, \mathrm{Si}, \mathrm{Mg}, \mathrm{Co}, \mathrm{Mn}, \mathrm{Zn}, \mathrm{Cd}, \mathrm{Fe}^{2+}, \mathrm{Fe}^{3+}, \mathrm{Ge}$, $\mathrm{Cu}, \mathrm{Ga}$,

$\mathrm{T}^{2}: \mathrm{B}, \mathrm{Be}, \mathrm{Al}, \mathrm{Si}, \mathrm{Fe}^{3+}, \mathrm{Ga}, \mathrm{Ge}$,

$\mathrm{A}: \mathrm{O}, \mathrm{F}, \mathrm{S}$.

$\mathrm{X}$ は大きな陽イオン, $\mathrm{T}^{1}, \mathrm{~T}^{2}$ は四面体席を占める陽イオ ン, $\mathrm{A}$ は陰イオンである. 多数の合成実験からメリライト ではこれら多様な元素間で幅広い固溶体を形成すること も知られている.

メリライトの結晶構造は Warren ${ }^{2)}$ により最初に明らか にされた $\left(P \overline{4} 2{ }_{1} m, a=7.84, c=5.03 \AA\right)$. 構造中では $\mathrm{T}^{1} \mathrm{~A}_{4}$, $\mathrm{T}^{2} \mathrm{~A}_{4}$ 四面体が $\mathrm{A}$ 原子を介し互いに連結して (001) 面に平行 な層を形成し，大きな $\mathrm{X}$ 原子が層間に挟まれている層状構 造である. Xの周りの A 原子の配位は 8 配位である (図 1). 1986 年に $\mathrm{Ca}, \mathrm{Mg}$ を含む合成メリライト $\left(\mathrm{Ca}_{2} \mathrm{MgSi}_{2} \mathrm{O}_{7}\right)$ が, 常温で強度の大きい主反射に加え, 弱い衛星反射を与える インコメンシュレート (IC) 相であることが発見された.3)
衛星反射は高温で消失し, IC 相はノーマル相 (N 相)に可 逆的に転移する. 以後多くの研究者がこの物質に注目し, 物性測定, 変調構造の安定条件の探索, 変調構造の解明な どを目指し幅広い研究がなされた. 衛星反射はX原子と して Ca を含む試料の回折像に主に観察されている. 天然 のメリライトの回折像にも衛星反射が観察されている.4)

$\mathrm{IC}$ 相の最初の構造決定は $\mathrm{Co}$-誘導体 $\left(\mathrm{Ca}_{2} \mathrm{CoSi}_{2} \mathrm{O}_{7}\right)$ の試 料を用いて行われた.5),6) 構造の変調は二次元変調であり, 衛星反射も含めた回折データを五次元空間で取り扱うこ とにより決定された，その結果，構造変調は $c$ 軸に垂直な 方向の原子変位による二次元変調であること, IC 相の構

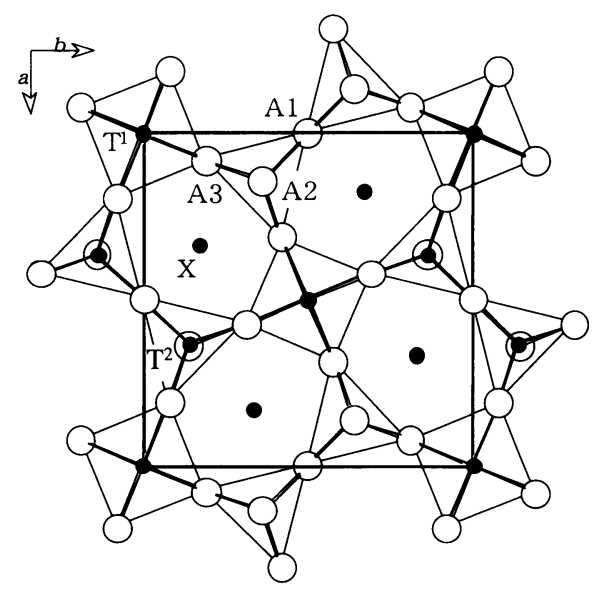

図 1 Meliliteの構造の (001) 面への投影. (Projection of the Melilite structure on (001) plane.) 四角形は $\mathrm{T}^{1} \mathrm{~A}_{4}$ 四面体，三角形は $\mathrm{T}^{2} \mathrm{~A}_{4}$ 四面体を表している. 
造では $\mathrm{Ca}$ 原子を取り囲む $\mathrm{O}$ 原子の数 ( $\mathrm{Ca}$ の配位数) が変 調波に従って変化しており, $\mathrm{Ca}$ の周りの $\mathrm{O}$ 原子の配位数 は6配位から8配位のものまで存在することが明らかに された (図2)。この物質の $\mathrm{N}$ 相への転移が $493 \mathrm{~K}$ で可逆 的に起こることも同時に見出された。

本研究は $\mathrm{Ca}_{2} \mathrm{CoSi}_{2} \mathrm{O}_{7}$ (IC 相) の構造解析で求められた結 果を基に, 以下の諸点を明らかにするために行った。

1. 異なる配位数 ( $6 \sim 8$ 配位) をもつ $\mathrm{Ca}$ の IC 構造中に抄 ける分布の様式

2. $\mathrm{Ca}_{2} \mathrm{CoSi}_{2} \mathrm{O}_{7}$ 以外の組成をもつ IC 相の構造と $\mathrm{Ca}_{2} \mathrm{CoSi}_{2} \mathrm{O}_{7}$ の構造との共通性

3. IC 相の変調波ベクトルの一次成分 $q$ 值の温度変化と相 転移

4. $q$ 值の温度変化に伴う変調構造の変化

本研究の試料には FZ 法で合成した $\mathrm{Ca}_{2} \mathrm{MgSi}_{2} \mathrm{O}_{7}(\mathrm{Mg}-$

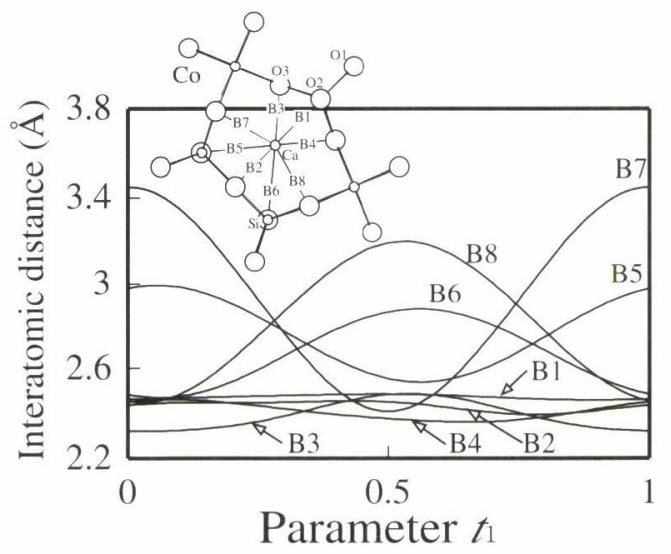

図2 $\mathrm{Ca}_{2} \mathrm{CoSi}_{2} \mathrm{O}_{7}$ における位相 $t_{1}$ に対する $\mathrm{Ca}-\mathrm{O}$ 結合距離 の変化. (Variations of $\mathrm{Ca}-\mathrm{O}$ distances of $\mathrm{Ca}_{2} \mathrm{CoSi}_{2} \mathrm{O}_{7}$ as functions of the parameter $t_{1}$.) $\left(t_{2}=0.0\right)$. B1 B8 は挿入した構造図の $\mathrm{Ca}-\mathrm{O}$ 結合距離に対応する。
誘導体)， $\mathrm{Ca}_{2} \mathrm{Mg}_{0.55} \mathrm{Fe}_{0.45} \mathrm{Si}_{2} \mathrm{O}_{7}(\mathrm{Mg}-\mathrm{Fe}$ 固溶体) および $\mathrm{Ca}_{2} \mathrm{CoSi}_{2} \mathrm{O}_{7}$ ( $\mathrm{Co}$-誘導体) の単結晶を用いた. 研究にはX $\mathrm{X}$ 線 回折デー夕（100～770 K の温度範井で測定）を用いた構 造解析と, 新たに開発したシミュレーション法を併用し た.7) 変調に伴う衛星反射の例として Co-誘導体の室温に おける回折パターンを示す (図3). 以下に得られた結果を 示す.

\section{IC 相における 6 配位の $\mathrm{CaO}_{6}$ 多面体の分布}

メリライトのIC構造は前記のように五次元空間で解析 され, 記述されている. 本研究では通常の三次元空間にお ける IC 構造のイメージを得るために, 五次元構造解析で 決定した構造パラメータを後述の式 (1) などを用い三次 元空間に変換し, IC 構造の特徵を検討した. IC 構造は三 次元空間では变調波の方向に周期性をもたないが, $c$ 軸方

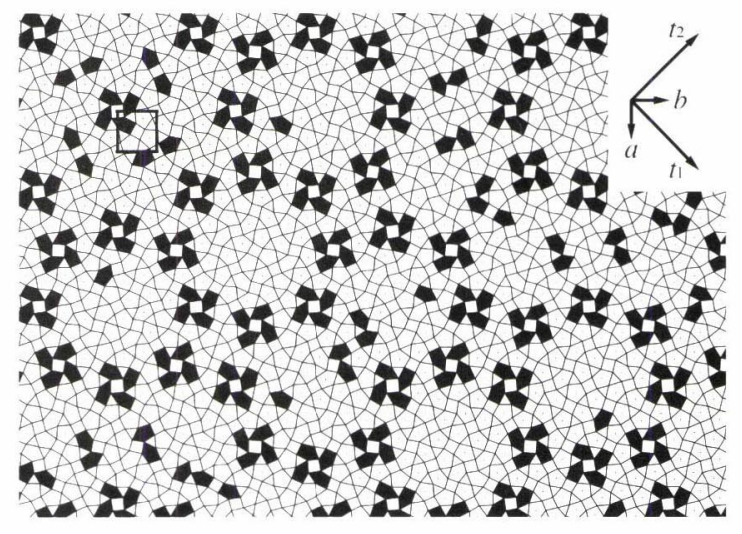

図4 $\mathrm{Ca}_{2} \mathrm{CoSi}_{2} \mathrm{O}_{7}$ における IC 構造の一部一 (001) 面投 影一. (part of IC structure in $\mathrm{Ca}_{2} \mathrm{CoSi}_{2} \mathrm{O}_{7}$ - projected on (001) plane.) 四角形は $\mathrm{CoO}_{4} 4$ 面体, 三角形は $\mathrm{SiO}_{4} 4$ 面体, 五角形は $\mathrm{CaO}_{6}$ 多面体, 点は $\mathrm{Ca}$ 原子を 表す. 6 配位の $\mathrm{CaO}_{6}$ 多面体は黒く塗りつぶしてし てある。

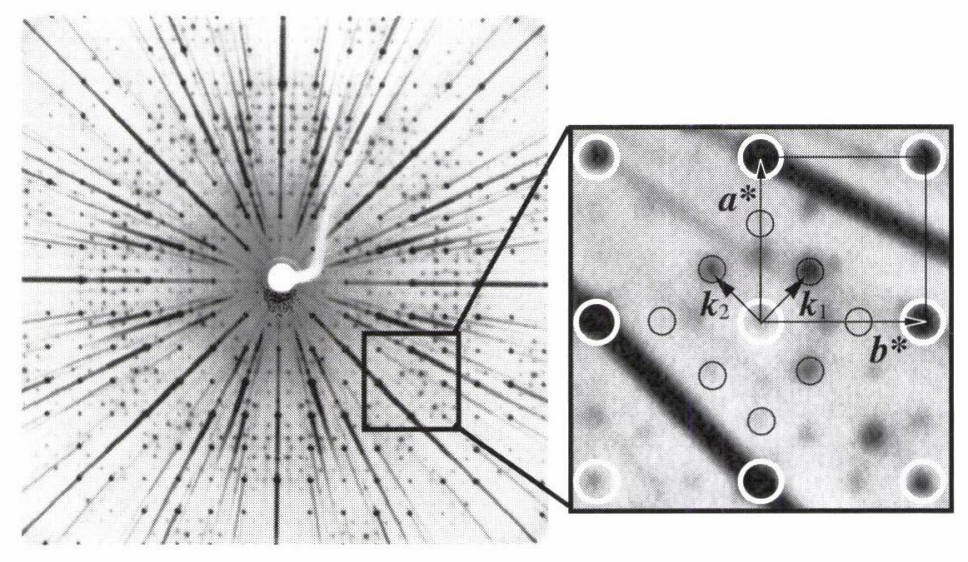

図3 $\mathrm{Ca}_{2} \mathrm{CoSi}_{2} \mathrm{O}_{7}$ の室温プリセッション写真. (Precession photograph of $\mathrm{Ca}_{2} \mathrm{CoSi}_{2} \mathrm{O}_{7}$ at room temperature.) (hk0 net). $\boldsymbol{k}_{1}, \boldsymbol{k}_{2}$ は変調波ベクトルを表し, 白丸で囲まれた反射が主反射, 黑丸で囲まれた反射が衛星反射をそれぞれ示す. 
向には周期性を有する，構造の比較を容易にするために， 以後すべての IC 構造図は原点の $\overline{4}$ 軸を含む領域の二次元 投影図で示す (図 4, 図6など). $c$ 軸の周期が短く構造の 重なりがないので投影図を用いている。また6配位の $\mathrm{CaO}_{6}$ 多面体の分布に注目するために, $\mathrm{CaO}_{6}$ 多面体は黒く 塗りつぶしてある。

$\mathrm{Ca}_{2} \mathrm{CoSi}_{2} \mathrm{O}_{7}$ に扔ける $\mathrm{CaO}_{6}$ 多面体の形状は歪んだ 8 面体 であり，正方晶系の $c$ 軸に沿い鎖状に連なっている，構造 図では鎖状配列は単独の場合もあるが, 多くは4 本の鎖状 配列が $\mathrm{CoO}_{4}$ 4面体で結ばれた束状配列 (以後 bundles と呼 ぶ）を形成している. bundles を形成する $\mathrm{CoO}_{4} 4$ 面体はほ かのものに比べ変型が大きく $c$ 軸方向につぶれ $a b$ 方向に 広がっている. ${ }^{8)}$ IC 構造の最も著しい特徴は, 多くの bundles がさしわたし約 $30 \AA ̊ 丿$ の 8 角形の配列をしていることであ る. また 8 角形の一部が欠落した不完全な 8 角形も数多く 存在し，8角形形成の強い傾向が見られる. IC 構造なので 8 角形の分布には周期性は見られない (図 4). bundles の 作る 8 角形は Co-誘導体ばかりでなく, $\mathrm{Mg}$-誘導体, $\mathrm{Mg}$ $\mathrm{Fe}$ 固溶体の構造中にも多数見られ, メリライトの IC 構造 を特徵づけるものであると結論づけられる.91

構造解析で見出された 8 角形のパターンは, 高分解能電 子顕微鏡 (HRTEM) 像でも観察されている. Heurck ら 10) は $\mathrm{Ca}_{2} \mathrm{ZnGe}_{2} \mathrm{O}_{7}$ の IC 相の HRTEMによる直接観察を行い多 数の 8 角形のパターンを観察した. 彼らはパターンの解釈 にあたってコメンシュレートな変調周期 $(q=2 / 7)$ といく つかの異なったサブユニットの存在を仮定し, サブユニッ トを組み合わせることにより 8 角形パターンの成り立ちの 説明を試みたが，6配位の $\mathrm{CaO}_{6}$ 多面体の形成する bundles の存在は導けなかった. 彼らの示したHRTEM像の中には 分解能が高く非常に鮮明なものがあり, $\mathrm{CaO}_{6}$ 多面体の鎖 状配列に対応する輝点が観察でき bundles も識別できる。 HRTEM 像でも 8 角形の分布に周期性は見られない.

\section{3. 変調構造の温度変化と相転移}

$\mathrm{Mg}$-誘導体の IC 相の衛星反射は $357.9 \mathrm{~K}$ で消滅し $\mathrm{N}$ 相 に可逆的に転移する.3) また Seifert ら 11) は $\mathrm{Ca}_{2} \mathrm{MgSi}_{2} \mathrm{O}_{7}$ 一 $\mathrm{Ca}_{2} \mathrm{FeSi}_{2} \mathrm{O}_{7}$ 系では IC 相は $\mathrm{Fe} /(\mathrm{Fe}+\mathrm{Mg})$ 比が 0.0 から 0.7 の範囲で存在し, IC 相から $\mathrm{N}$ 相への転移温度は $\mathrm{Fe}$ の増加 に伴い $358 \mathrm{~K}$ から $523 \mathrm{~K}$ へ上昇することを見出した. 彼ら の研究では $q$ 值が温度上昇とともに減少することも観察 された. Kusaka ${ }^{7.99}$ は前記 3 種類の単結晶試料の $\mathrm{X}$ 線回折 デー夕を用い $q$ の変化に伴う IC 構造の変化の研究, $\mathrm{N}$ 相 の構造決定を行った. 3 試料の $q$ 值は温度上昇とともに減 少し, Co 誘導体は $493 \mathrm{~K} て ゙, \mathrm{Mg}$ 誘導体は $360 \mathrm{~K} て ゙, \mathrm{Mg}-\mathrm{Fe}$ 固溶体は $510 \mathrm{~K}$ で衛星反射が消滅し $\mathrm{N}$ 相に可逆的に転移 する. IC 構造中の bundles の数と bundles の 8 角形配列の 数は高温になるほど減少する

IC 構造の温度変化の詳細を知るためにわれわれは Co
誘導体につき，常温から高温相 $(\mathrm{N}$ 相) までの温度を変え た IC 構造, 平均構造 (衛星反射を除き主反射のみから求 めた構造)， $\mathrm{N}$ 相の構造，などの解析から温度上昇に伴う 変調波の乱れの発生と変化の研究を行った. 非等方性変位 棈円体の主軸の長さの温度変化は特異な挙動を示し, その 挙動から各原子の变調に基づく变位成分, 見かけの熱振動 成分, 変調波の乱れの成分を分離できる，それぞれの成分 を分離した結果, 常温ではほとんど見られない変調波の乱 れの成分が温度上昇とともに発生し増大することが判明 した.また転移点を少し超えた温度では鋭い衛星反射は消 滅するものの, 衛星反射の位置を結ぶような環状の散漫散 乱が観察されることから，N相の構造には 6 配位の $\mathrm{CaO}_{6}$ 多面体の作る bundles の 8 角形配列もしくはその一部が残 存していることが推論される.なお IC 相の平均構造と N 相の構造間には違いがほとんど認められなかった.9),12)

メリライトの低温形の存在は早くから予想されていた. $\mathrm{Ca}_{2} \mathrm{CoSi}_{2} \mathrm{O}_{7}$ の IC 相が温度を下げると $160 \mathrm{~K}$ でコメンシュ レートに近い相 $(q=0.324)$ に転移することが, 最初に Riesterら13)により見出された，相転移には著しいヒステ リシスが伴う。われわれは $\mathrm{Ca}_{2} \mathrm{CoSi}_{2} \mathrm{O}_{7}$ の $q$ 值の温度変化 から IC 相が $242.3 \mathrm{~K}$ でC 相 $(q=1 / 3)$ に転移すること, ヒ ステリシスが $\mathrm{N}$ 相への転移温度 $(493 \mathrm{~K})$ までの IC 相の全 安定領域で観察されること (図5)を明らかにした.7) C 相 から IC 相への昇温に伴う相転移は約 $280 \mathrm{~K} て ゙$ 起こる。 コ メンシュレートに近い構造は Riester ら 141により高次元空 間における取り扱いで決定され，正方晶系の対称 $(p \overline{4}$ の回 折対称）をもつ個体の双晶であることが判明した. コメン シュレート相 (C 相) は周期性があることから三次元空間 における通常の取り扱いで解析された，その結果みかけの 回折対称は正方晶系であるが, 斜方晶系 $\left(P 22_{1} 2{ }_{1} 2\right)$ の個体 が双晶したものであり, 結晶構造も前者と異なることが明

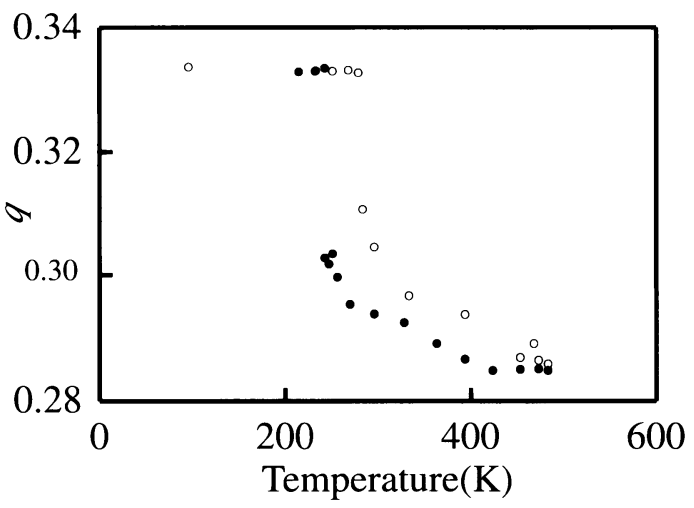

図 $5 \mathrm{Ca}_{2} \mathrm{CoSi}_{2} \mathrm{O}_{7}$ における変調波ベクトルの一次成分 $q$ 值の温度変化. (Variation in the magnitude $q$ of the modulation wave vectors versus temperature change.) : 降温過程 $\bigcirc$ : 昇温過程. 


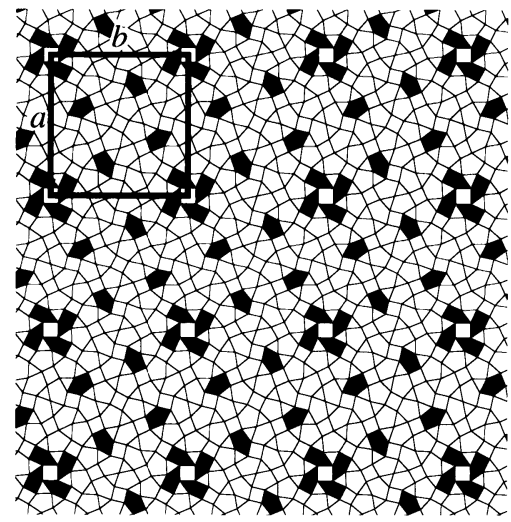

(a)

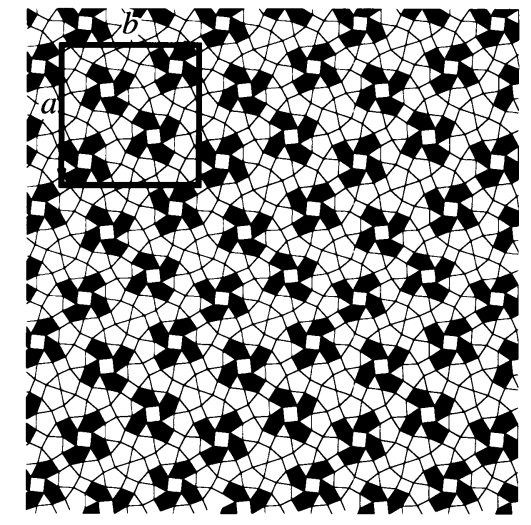

(b)

図6 $\mathrm{Ca}_{2} \mathrm{CoSi}_{2} \mathrm{O}_{7}$ の 相の構造図. (The structure of the commensurate $\mathrm{Ca}_{2} \mathrm{CoSi}_{2} \mathrm{O}_{7}$.) (a) $P \overline{4}$, (b) $P 2_{1} 2_{12}$, 黒四角形は単 位格子 (3 倍格子).

らかにされた (図6)。両構造の主な相違点は6配位の $\mathrm{CaO}_{6}$ 多面体と bundles の数である. 正方晶系の構造では全 $\mathrm{Ca}$ 席の $22.2 \%$ \% $\mathrm{CaO}_{6}$ 多面体でありその半数が bundles を 形成しているのに対し, 斜方晶系の構造では全 $\mathrm{Ca}$ 席の $44.4 \%$ \% $\mathrm{CaO}_{6}$ 多面体でありそのすべてが bundles の形成

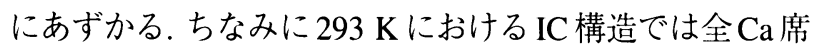
に対する $\mathrm{CaO}_{6}$ 多面体の数は $28.5 \%$ であり正方晶系の構 造中の割合よりも多く, 斜方晶系の構造中の割合よりも 少ない. また IC 構造で顕著であった 8 角形の配列は両構 造とも見られない.このように $\mathrm{Ca}_{2} \mathrm{CoSi}_{2} \mathrm{O}_{7}$ の低温相とし て 2 種類のものが報告されているが, 2 種類の安定関係は 不明である。

低温形への相転移は, $\mathrm{Mg}$-誘導体, $\mathrm{Mg}-\mathrm{Fe}$ 固溶体ともに $100 \mathrm{~K}$ までは見出されなかった。 また $\mathrm{Mg}$-誘導体と $\mathrm{Zn}$-誘 導体 $\left(\mathrm{Ca}_{2} \mathrm{ZnSi}_{2} \mathrm{O}_{7}\right)$ についてのその後の研究で, 低温相へ

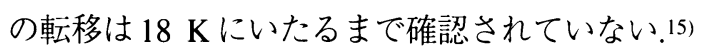

\section{4. 構造シミュレーション}

变調構造における原子 $j$ の位置ベクトル $\mathbf{x}_{j}$ は, 基本格 子 (主反射に対応する格子) の格子ベクトルを $\mathbf{n}$, 基本構 造 (主反射から導いた構造)における位置べクトルを $\overline{\mathbf{x}}_{j}$, 变位べクトルを $\mathbf{u}_{j}$ とすると, $\mathbf{x}_{j}=\mathbf{n}+\overline{\mathbf{x}}_{j}+\mathbf{u}_{j}$ で表される. 原子 $j$ の变位量 $u_{i j}(q)$ ( $i$ は $1,2,3$ でそれぞれ $x, y, z$ に対 応)は下式で表される。

$$
\begin{aligned}
u_{i j}(q)= & \sum_{m} \sum_{n}\left[A_{i j}^{m n} \cos 2 \pi\left(m t_{1}+n t_{2}\right)\right. \\
& \left.+B_{i j}^{m n} \sin 2 \pi\left(m t_{1}+n t_{2}\right)\right]
\end{aligned}
$$

ここで $q$ は変調波の一次波動べクトル大きさ, $A_{i j}^{m n}$ と $B_{i j}^{m n}$ は五次元の構造解析で求めた変調波のフーリ工係数であ る. また変数 $t_{1}$ と $t_{2}$ は原子位置 $\mathbf{n}+\overline{\mathbf{x}}_{j}$ における内部位相で あり，それぞれ $t_{1}=\mathbf{k}_{1} \cdot\left(\mathbf{n}+\overline{\mathbf{x}}_{j}\right)+t_{1}{ }^{0}, t_{2}=\mathbf{k}_{2} \cdot\left(\mathbf{n}+\overline{\mathbf{x}}_{j}\right)+t_{2}{ }^{0}$
と表される. $\mathbf{k}_{1}, \mathbf{k}_{2}$ は変調波ベクトルで $\mathbf{k}_{1}=q\left(\mathbf{a}^{*}+\mathbf{b}^{*}\right)$ と $\mathbf{k}_{2}=q\left(-\mathbf{a}^{*}+\mathbf{b}^{*}\right)$ で与えられる. $t_{1}{ }^{0}$ と $t_{2}{ }^{0}$ は初期位相, $\mathbf{a}^{*}$ と $\mathbf{b}^{*}$ は基本逆格子 (主反射の与える逆格子)の基底べク トルである.また $m$ と $n$ は衛星反射の指数である。これら の式により高次元空間の構造は三次元空間に変換できる.

一方温度を変えた回折実験から, インコメンシュレート 相の回折像に下記の $2 つ の$ 特徵が見出された.

(a) 衛星反射間の相対的な強度が温度の変化にかかわらず ほとんど変わらない．

(b) 高次の衛星反射が低温における長時間露光でわずかに 観察される程度に弱い。

この特徵から, 高次元空間に扔ける構造変調は温度の変 化に対して不変であり, $q$ 值の変化による変調波間の相対 的な位相変化は五次元格子の歪みによって引き起こされ ると考えてよい.そこで以下に示すシミュレーション法を 考案した.

簡単な考察から $\left|A_{i j}^{m n}\right|<<1,\left|B_{i j}{ }^{m n}\right|<<1$ の条件を满足すれば, 衛星反射の強度 $I_{m n}$ は変調波の振幅を表すフーリエ係数の 2 乗に比例することがわかる. 構造解析から求めた結果は 上の条件を満足することを示し, 温度 $T$ における变位の大 きさ $u_{i j}(q, T)$ は,

$$
\begin{aligned}
u_{i j}(q, T) \approx & {\left[I^{1 / 2}(T) / I^{1 / 2}\left(T_{0}\right)\right] } \\
& \sum_{m} \sum_{n}\left[A_{i j}^{m n} \cos 2 \pi\left(m t_{1}+n t_{2}\right)\right. \\
& \left.+B_{i j}^{m n} \sin 2 \pi\left(m t_{1}+n t_{2}\right)\right]
\end{aligned}
$$

と表すことができる.ここで $A_{i j}^{m n} と B_{i j}^{m n}$ は温度 $T_{0}$ における 変調波の振幅, $t_{1}$ と $t_{2}, m$ と $n$ は式 (1) と同じである.ここ で $T_{0}$ は変調構造の解析で変調波のフーリ工係数を決定し

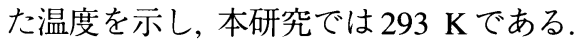

式 (2)の妥当性は実際の構造解析からも確かめられた。 
すなわち高温域 $(468 \mathrm{~K}, q=0.298)$ では, 測定強度を用 いて解析した構造と式 (2) から求めた構造とが一致した.16) 一方, 低温相 $(q=1 / 3)$ の回折強度の測定は $h 00$ と $0 k 0$ の 回折に対し $h=2 \mathrm{n}, k=2 \mathrm{n}$ のみ観測可能の回折条件を示 した. 初期位相に $(1 / 2,0)$ を与えた斜方晶系の構造が測 定した回折条件と一致したために, 式(2) から導いた原子 座標と空間群を用いて最小二乗法による構造精密化を行 ったところ, 観測強度と計算強度が良い一致を示し C 相 $(q=1 / 3)$ の構造を決定することができた.17)これに対し Riester ら 14) の示した低温相 $(q=0.324)$ の構造の回折対 称は $p \overline{4}$ で, 回折条件 (消滅則) を与えない. $q=0.324$ でシ ミュレーションにより構築した IC 構造は, $q=1 / 3$ で初期 位相に $(0,0)$ を与えて求めた構造 $(P \overline{4})$ の領域と, 同じく
初期位相 $(1 / 2,0)$ を与えた斜方晶系 $\left(P 2{ }_{1}{ }_{1} 2\right)$ のC相の構 造の領域が混在したものであり, 前者の領域が大きい. $q=1 / 3, P \overline{4}$ で式(2) を用い構築した構造は, Riester らの報 告した構造と一致した。

以上の結果から, 式 (2) を用いて IC 構造や低温相の構 造ばかりでなく,$q$ の変化の領域すべてにわたってこの物 質の変調構造を実現できることが判明した.

\section{IC 相の構造変化と大規模規則性}

IC 相から低温相までの変調構造では bundles の数に変 化が見られた。また IC 構造中では bundles 98 角形配列 の形成が顕著に見られた. そこで, $\mathrm{CaO}_{6}$ 多面体鎖, bundles, bundles の作る 8 角形配列, などの変調構造を特徴づける

表 $1 q=\mathrm{N} / \mathrm{M}$ をつコメンシュレート構造の可能な空間群と初期位相 $\left(t_{1}^{0}, t_{2}^{0}\right)$ の関係. (Relation between initial phases $\left(t_{1}^{0}, t_{2}^{0}\right)$ and possible space groups of commensurate structure with $q=$ N/M. $)$ 表示したもの以外の初期位相をも つ構造の対称性は $P 1$ である. $\mathrm{CaO}_{6}$ 多面体と bundles の数をかぞえた独立な領域も示す.

\begin{tabular}{l|l|l|l|l}
\hline$M$ & Even & \multicolumn{5}{l}{} \\
\hline Cell parameter & $M a / 2^{1 / 2}$ & $=\left(2 n_{1}+1\right) / 2 M$ & $=\left(2 n_{1}+1\right) / 2 M$ & $\neq\left(2 n_{1}+1\right) / 2 M$ \\
\hline$t_{1}^{0}$ & $=n_{1} / M$ & $=\left(2 n_{2}+1\right) / 2 M$ & $\neq\left(2 n_{2}+1\right) / 2 M$ & $=\left(2 n_{2}+1\right) / 2 M$ \\
\hline$t_{2}^{0}$ & $=n_{2} / M$ & $P b a 2$ & $P a$ & $P a$ \\
\hline Space group & $P 4$ & $0 \leq t_{1}^{0}<1 / M$ and $0 \leq t_{2}^{0}<2 / M$ & \\
\hline Independent ranges & Odd & $=\left(2 n_{1}+1\right) / 2 M$ & $=\left(2 n_{1}+1\right) / 2 M$ & $\neq\left(2 n_{1}+1\right) / 2 M$ \\
\hline$M$ & $M a$ & $=\left(2 n_{2}+1\right) / 2 M$ & $\neq\left(2 n_{2}+1\right) / 2 M$ & $=\left(2 n_{2}+1\right) / 2 M$ \\
\hline Cell parameter & $=n_{1} / M$ & $P 2_{1}$ & $P 2_{1}$ \\
\hline$t_{1}^{0}+t_{2}^{0}$ & $=n_{2} / M$ & $P 2_{1} 2_{1} 2$ & \\
\hline$-t_{1}^{0}+t_{2}^{0}$ & $P 4$ & &
\end{tabular}
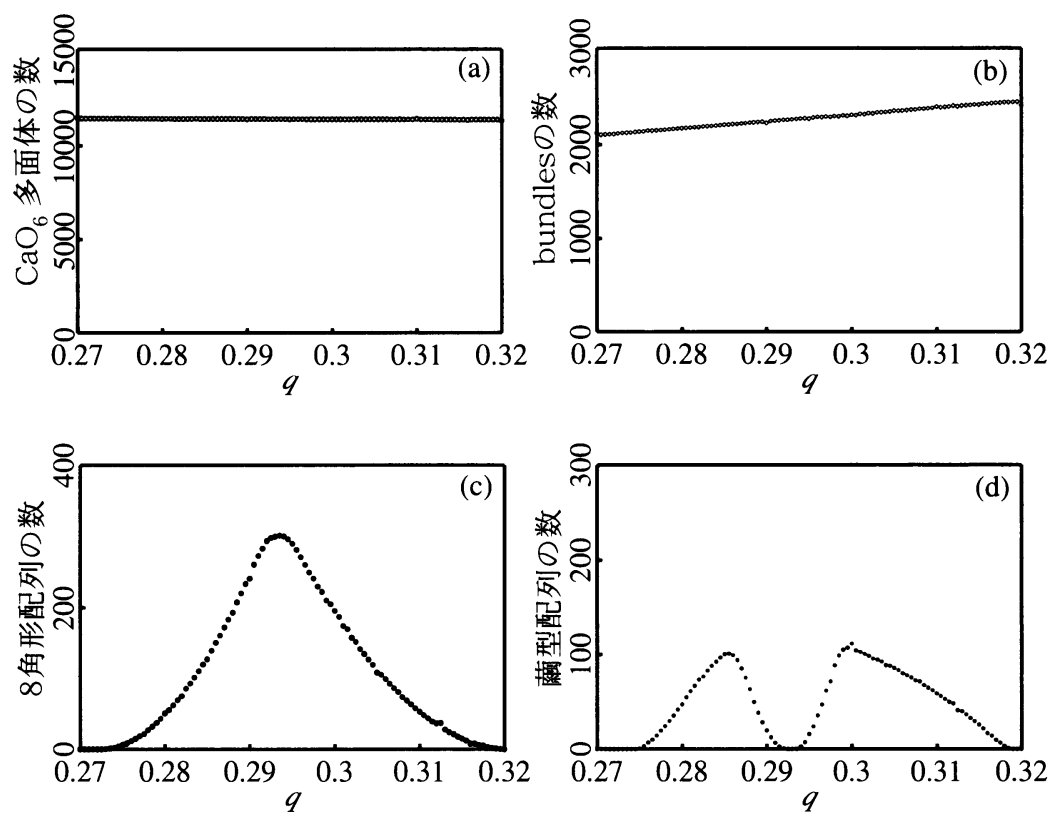

図 7 (a) $\mathrm{CaO}_{6}$ 多面体, (b) bundles, (c) 8 角形配列, (d) 藏型配列の数の $q$ に対する変化. (Variation of the numbers of (a) $\mathrm{CaO}_{6}$ polyhedra, (b) bundles and (c) octagons versus q.) 
0.285
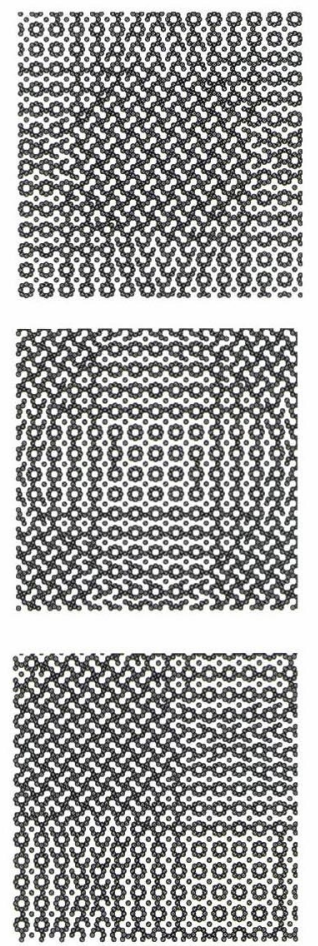

0.289
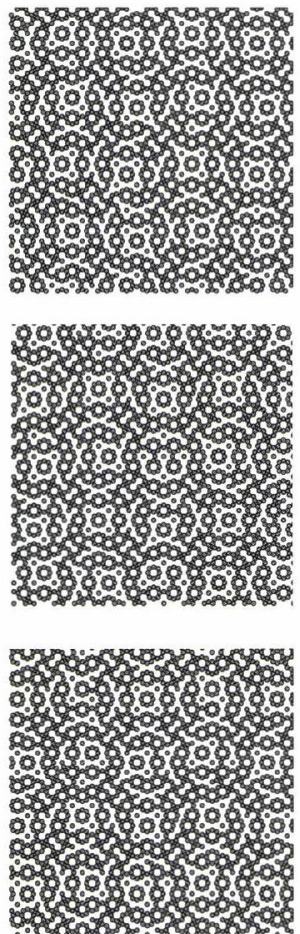

0.293
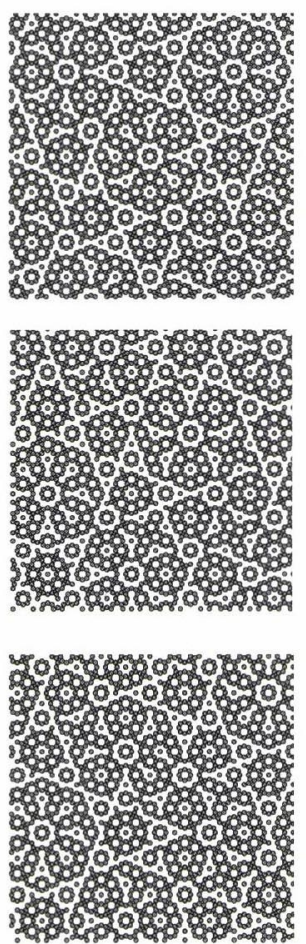

0.297
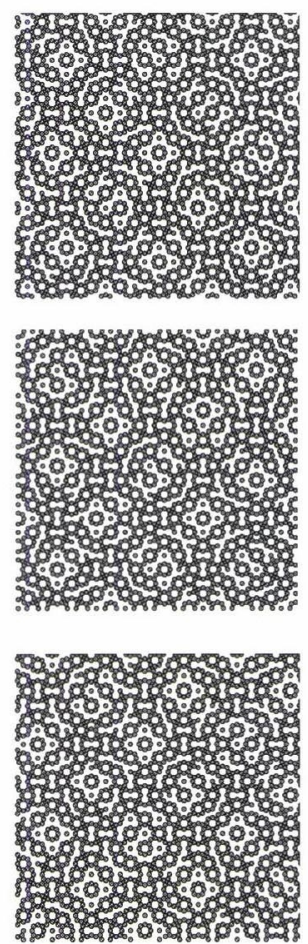

0.301
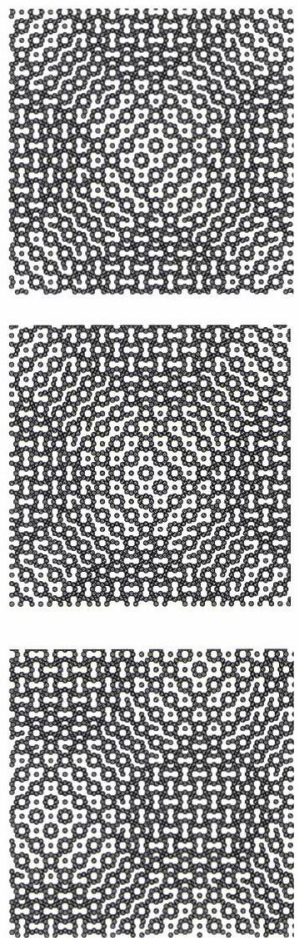

図 8 qが 0.285 から 0.301 をもつ構造に扔ける bundlesの分布. (Schematic diagrams of the distribution of the complete bundles in the range of $q$ between 0.285 and 0.301.) 黒丸が 1 つの完全な bundlesに対応する. 描画領域は $100 a \times$ $100 a$ である. 初期位相 $\left(t_{1}, t_{2}\right)$ は上段の構造が $(0,0)$ で, 中段は $(1 / 400,201 / 400)$ で, 下段が $\left(2^{1 / 2 / 10}, 3^{1 / 2} / 10\right)$ で 描画した。

構造要素の数が $q$ 值の違いによりどう変化するか,$q$ 值の 異なった構造にほかの構造要素が生じるか否かを知るた めに, 式(2)を用いたシミュレーションにより, 各構造要 素数の変化や, その他の構造要素の有無の検討を行った.188 $\mathrm{IC}$ 相の構造は, 原点に扔ける対称性を除くと周期性がな く同じ構造は現れないために, $100 a \times 100 a(a$ は基本格 子の $a$ 軸の長さ) の範囲でシミュレーションを行った. $q$ 值の変化範囲は $0.27 \sim 0.32$ (観測範囲は $\mathrm{C}$ 相を除くと $0.285 \sim 0.310$ である) と変化幅 $\Delta q=0.0005$ で, 初期位相 の変化の範囲は $t_{1}^{0}, t_{2}^{0}$ ともに $0.0 \sim 0.9$ で変化幅は $\Delta t=0.1$ である. シミュレーションに際し,$q=\mathrm{N} / \mathrm{M}$ が比較的簡単 な有理数 (M が比較的小さな整数)の場合は構造は周期性 をもち高い対称を示すので, 構築した構造の独立な範囲 （非対称単位）に制限が生じる，その場合には対称性に応 じた処置を行った(表1).

IC 構造の安定域全体の特徵を概観するために $\mathrm{CaO}_{6}$ 多 面体鎖の数, bundlesの数, bundles の作る 8 角形配列の数 (欠損のない完全な 8 角形配列のみ) の計数の結果をグラ フ化したものが図7である. 図から明らかなように, $\mathrm{CaO}_{6}$ 多面体鎖の数は $q$ 值の変化の範囲で一定であるが, bundles の数は $q$ 值の増加に比例して少しずつ増加する.すなわち 温度が低下するに従って構造中の bundles の数は増加す る. 図 $7 \mathrm{a}$ と図 $7 \mathrm{~b}$ の比較から, $74 \sim 86 \%$ の $\mathrm{CaO}_{6}$ 多面体
鎖が bundles の形成に寄与していることが判明した.また bundlesの数が温度の低下に伴い漸増していることから， 変調構造では $\mathrm{CaO}_{6}$ 多面体鎖に bundles を形成する傾向が あると言える。一方 bundlesの8 角形配列 (一辺が12.4 ̊) の数は $q$ 值の変化に対しピーク状の分布を示し (図 7c), $q$ 值が 0.2935 で最大值になる. 最大值では約 $83 \%$ の bundles が8角形の形成にかかわっている. 8角形配列の值は実験 で観測された IC 相の安定領域 $(q=0.284 \sim 0.305)$ の中で 著しい増大を示し, 安定領域外では小さな值になってい る。また低温相には 8 角形配列は見られない,このことか ら bundlesの 8 角形配列は IC 相に扔ける最も顕著に見ら れる構造要素であり,この構造要素の多量の形成が IC 相 形成の最も重要な要因であると考えられる. bundlesの集 合には 8 角形ばかりでなく, 8 角形を 2 個以上組み合わせ たさまざまな形のものが生じることが初期位相を変えた シミュレーションから判明した，それらのほとんどは $100 a \times 100 a$ の範囲内での数は少なく構造要素としての

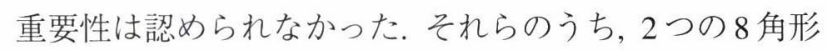
を接合させた 15 個の bundles からなる薁型の配列がほか のものより頻度が高く生じることが判明し, それらの計数 も行った (図7d). 興味あることに 8 角形配列が非常に多 い $q$ 值の領域では蕨型配列は少なく, 8 角形配列が減少す る領域で2カ所にピークを示す. 
$2 / 7$ มoف 300000000010

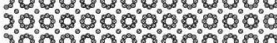

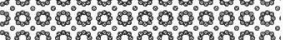
30000000001000 $3010000000 \%$ 1000

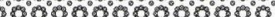

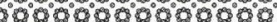

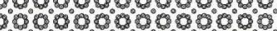
3.
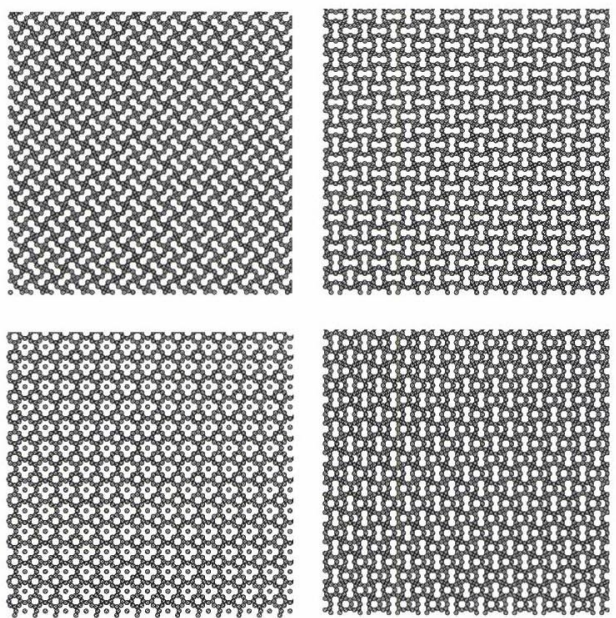

図 $9 q$ が2/7, および3/10のC構造の bundles 分布 (Schematic diagrams of the distribution of the complete bundles for commensurate structure with $q=2 / 7$ and 1/10.) 黒丸が完全な bundles 表す。描画領域 は $100 a \times 100 a$ であり，初期位相 $\left(t_{1}, t_{2}\right)$ は，上段 は両構造ともに $(0,0)$, 中段は $q=2 / 7$ の構造が $(0$, $1 / 2), q=3 / 10$ の構造が $(1 / 20,11 / 20)$, 下段は両 構造ともに $\left(2^{1 / 2} / 10,3^{1 / 2} / 10\right)$ である.

$q$ 值と初期位相 $\left(t_{1}^{0}, t_{2}^{0}\right)$ のわずかな違いにより変調構造 がさまざまに变化する様子を図 $8 * 1$ に示す。この変化量 $(\Delta q=0.004)$ は $q$ 值の $1.4 \%$ にすぎない. 1列目の各図の 初期位相は $(0,0)$ で, 2 列目の各図の初期位相は (1/401, 201/400) で, 3 列目は $(\sqrt{2} / / 10, \sqrt{3} / / 10)$ の初期位相で構築 したものである. $q=0.285$ と $q=0.301$ のシミュレーショ ンでは，3種類の初期位相で構築した構造はみな 8 角形配 列と藏型配列が主な構造要素であり, 8 角形配列は孤立し た bundles とともに帯状の構造を作っている，藏型配列の 長軸の方向は $q=0.285$ の場合が $<110>$ に平行, $q=0.301$ では $<100>$ に平行である. 帯状構造の幅は, $q=0.285$ の 構造では約 $350 \AA, q=0.301$ では約 $210 \AA$ である. $q=$ 0.289 と $q=0.297$ の構造では間隔が約 $210 \AA$ の擬似周期 性が見られ，周期の方向は前者で<100>に平行，後者で $<110>$ に平行である. $q=0.293$ の構造はほかの 4 構造と

*1 コンピュータでは無理数を正確には表現できず, $q$ 值はみな厳密 には有理数である。しかしながら描いた構造は一般に非常に長 い周期をもつので, 無理数の $q$ 值の構造の特徽を示していると 考えられる.
まったく異なり, bundlesの8 角形配列がさらに8 角形を 構成するように配列している. bundles の 8 角形の規則的 な配列が $q$ 值が有理数の場合に見られる. $q=0.2857(q$ 〜 $2 / 7)$ と $q=0.3(q=3 / 10)$ の構造を初期位相 $(0,0)$ で構築 すると, すべての 8 角形の中心が大きな正方格子の格子 点と一致するように分布している (図9). 格子の周期長は 両構造とも約 $55 \AA$ である. 正方格子は $q=0.2857$ では $\langle 100\rangle, q=0.3$ では $\langle 110\rangle$ に平行である. 両者とも初期 位相が変わると8 角形を主体とした構造から藏型を主体 とした配列に変化する。これら $2 つ の q$ 值に対応する構造 が方位は互いに 45 度異なるものの同じ構造を示すのは， 回折像における衛星反射の分布が正 8 角形になる条件 $q=$ $0.2928932 \ldots(q=1-1 / \sqrt{2})$ と上の $2 つ の q$ 值 $(q=0.2857$ と $q=0.3)$ との差がそれぞれほぼ等しいことに起因する と考えられる。

五次元空間におけるインコメンシュレート構造の構造 パラメータの情報は, 2 つの内部位相 $t_{1}$ と $t_{2}$ を座標軸とす る周期単位内 (以後 $\left(t_{1}, t_{2}\right)$ 領域と呼ぶ) で連続的な数值の 変化として表現される.199,20)これに対しコメンシュレート 相では変調周期と主反射の与える基本格子の周期の比が 有理数であることから, 構造の情報は $\left(t_{1}, t_{2}\right)$ 領域におい て離散的に分布する点 $(n q, n=0,1,2,3, \ldots)$ の数值で与 えられる. 例えば $q=1 / 3$ の場合には, 変調構造のすべて の情報は, $\left(t_{1}, t_{2}\right)$ 領域における $t_{1}$ と $t_{2}$ の単位長の $n / 3(n=$ $0,1,2)$ の位置に局在する.構造情報のこの不連続性は, 三 次元空間における基本格子の原点と $\left(t_{1}, t_{2}\right)$ 領域の原点の 位置関係が変化すると,シミュレーションで異なった構造 をもたらすことを示す.この異なった構造は五次元空間と 三次元空間との異なった「交わり」に対応するので，コメ ンシュレート構造のシミュレーションにあたっては初期 位相 $\left(t_{1}^{0}, t_{2}^{0}\right)$ の選択が非常に重要になる. 低温形の構造の 項に期したように, 式(2)によるコメンシュレート構造の シミュレーションの際, 初期位相 $\left(t_{1}^{0}, t_{2}^{0}\right)$ の違いで異なっ た対称性の構造が出現するのはこの理由による. 一方イン コメンシュレート構造は, 異なった初期位相の与えるすべ ての構造を含んでいることになる。すなわちインコメンシ ユレート構造の特定の部分の構造が低温型として実現する ことを示す。このことはまた，IC 相から低温相への相転移 までのすべての構造変化は, 変調波の波形の変化によるも のではなく $q$ 值の変化による高次元格子の変形に基づく 変調波間の位相変化に起因する変化であると言える。

\section{謝 辞}

本研究を行うにあたり, 懇切な研究指導および多くの助 言をいただきました大政正明教授 (姫路工業大学名誉教 授), 萩谷健治博士 (兵庫県立大学助手) に深く感謝致しま す。また，試料を提供していただきました飯石一明教授 (山口大学)に心から感謝致します。 


\section{文 献}

1) M. Ohmasa, K. Hagiya and K. Kusaka: J. Min. Petrol. Sci. 97, 199 (2002).

2) B. E. Warren: Z. Kristallogr. 74, 131 (1930).

3) B. S. Hemingway, H. T. Evans Jr, G. L. Nord Jr, H. T. Haselton Jr, R. A. Robie and J. J. McGee: Can. Mineral. 24, 425 (1986).

4) K. Hagiya, M. Ohmasa and K. Iishi: Proc. Jpn Acad. Ser. B, 68, 25 (1992).

5) K. Hagiya, M. Ohmasa and K. Iishi: Acta Cryst. B49, 172 (1993).

6) L. Bindi, P. Bonazzi, M. Dusek, V. Petricek and G. Chapuis: Acta Cryst. B57, 739 (2001).

7) K. Kusaka: PhD thesis, Himeji Institute of Technology, Japan (1999).

8) K. Kusaka, M. Ohmasa, K. Hagiya, K. Iishi and N. Haga: Miner. J. 20, 47 (1998).

9) K. Kusaka, K. Hagiya, M. Ohmasa, Y. Okano, M. Mukai, K. lishi and N. Haga: Phys. Chem. Miner. 28, 150 (2001).

10) C. van Heurck, G. van Tendeloo and S. Amelinckx: Phys. Chem. Miner. 18, 441 (1992)

11) F. Seifert, M. Czank, B. Simons and W. Schmahl: Phys. Chem. Miner. 14, 26 (1987).

12) K. Kusaka, K. Hagiya, N. Haga, M. Ohmasa and K. lishi: Ferroelectrics 250, 71 (2001)

13) M. Riester and H. Böhm: Z. Kristallogr. 212, 506 (1997).

14) M. Riester, H. Böhm and V. Petricek: Z. Kristallogr. 215, 102 (2000).

15) B. Bagautdinov, K. Hagiya, S. Noguchi, M. Ohmasa, N. Ikeda, K.Kusaka and K. lishi: Phys. Chem. Miner. 29, 346 (2002).
16) K. Kusaka, K. Hagiya, M. Ohmasa and K. Tishi: Ferroelectrics 250, 79 (2001).

17) K. Hagiya, K. Kusaka, M. Ohmasa and K. Iishi: Acta Cryst. B57, 271 (2001).

18) K. Kusaka, K. Hagiya, M. Ohmasa and K. Iishi: Acta Cryst. B60, 369 (2004).

19) B. Bagautdinov, K. Hagiya, K.Kusaka, M. Ohmasa and K. Iishi: Ferroelectrics 250, 59 (2001).

20) B. Bagautdinov, K. Hagiya, K.Kusaka, M. Ohmasa and K. Iishi: Acta Cryst. B56, 811 (2000).

プロフィール

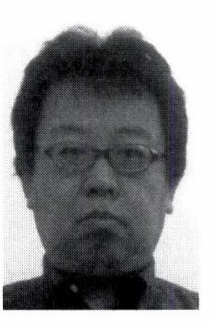

日下勝弘 Katsuhiro KUSAKA

日本原子力研究開発機構 量子ビーム応用研究部門

Japan Atomic Energy Agency (JAEA)

干 319-1195 茨城県那珂郡東海村白方白根 2-4

2-4 Shirane Shirakata, Tokai, Naka, Ibaraki 3191195, JAPAN

TEL. 029-282-6769, FAX. 029-284-3889

e-mail: kusaka.katsuhiro@.jaea.go.jp 最終学歴: 姫路工業大学大学院理学研究科博士課 程修了

専門分野：結晶学

現在の研究テーマ：中性子散乱実験装置開発お よび利用研究 